\title{
DINAMIKA KEPEMIMPINAN PONDOK PESANTREN
}

\author{
SAMSUL ARIFIN \\ STAI Al-Khairat, Pamekasan \\ coelzlamboe@gmail.com
}

\begin{abstract}
The writer conducted a qualitative research approach of social phenomenology; the data in this study were collected by using observation, in-depth interviews, and documentations. In order to articulate the leadership of the Islamic boarding school, the data has been analyzed by using qualitative methods with the mindset of deductive-inductive. The process of data analysis carried out in phases: data reduction, data presentation, and conclusion.

The dynamics of leadership in Islamic boarding school. The figure of Kiai is the central figure and more of it is a determinant factor to the success of students in the search for knowledge, leadership models used a model of democratic leadership. In that sense, all the information from the outside before being made policies (rules) boarding schools, first in the filter by a caregiver. Development programs are prioritized in formal and non-formal. The inhibitors of Islamic boarding school leadership, namely: Human Resource students, education funds, and the interest of society to change the tendency towards salafiyah and modern values. Supporting; Their means of education oriented to the development of students, and institutions that help students accommodate their talents and interests to develop.
\end{abstract}

\begin{abstract}
Abstrak
Pondok pesantren merupakan lembaga pendidikan Islam yang menempatkan sosok kiai sebagai tokoh sentral dan masjid atau surau sebagai pusat lembaganya. Lembaga ini merupakan institusi pendidikan Islam tertua di Indonesia dan sekaligus merupakan bagian dari warisan budaya bangsa (indigenous culture). Maka, bukanlah kebetulan jika pesantren masih dapat bertahan hingga saat ini.

Dinamika kepemimpinan di pesantren. Sosok kiai merupakan figur sentral dan lebih dari itu merupakan faktor determinan terhadap suksesnya santri dalam mencari pengetahuan, model kepemimpinan menggunakan model kepemimpinan demokrasi. Dalam artian, Semua informasi dari luar sebelum dijadikan kebijakan (aturan) pesantren, terlebih dahulu di filter oleh pengasuh. Pengembangan program diprioritaskan pada pendidikan formal dan non-formal. Penghambat dari kepemimpinan pesantren ini, yaitu: Sumber daya santri, Dana pendidikan, dan Minat masyarakat yang mengalami perubahan kecenderungan terhadap nilai salafiyah dan modern. Penunjangnya; Adanya sarana pendidikan yang berorientasi pada pengembangan santri, dan lembaga yang membantu santri mengakomodir bakat dan minatnya untuk berkembang.
\end{abstract}




\section{Kata Kunci: Dinamika, Kepemimpinan, Pondok Pesantren}

\section{Pendahuluan}

Pesantren merupakan lembaga pendidikan yang sudah "mendarah daging" di Indonesia. Sejarah pendidikan di Indonesia mencatat, bahwa pesantren adalah bentuk lembaga pendidikan pribumi tertua di Indonesia. Bahkan Nurcholis Madjid berpendapat bahwa pesantren tidak hanya identik dengan makna keislaman, tetapi juga mengandung makna keaslian (indigenous) Indonesia. Sebab keberadaannya mulai dikenal di bumi Nusantara pada periode abad ke 1317 M, dan di Jawa pada abad ke 15-16 M. Pendapat ini seolah mendapat justifikasi dengan tidak ditemukannya lembaga pesantren di negara-negara Islam lainnya.

Terlepas dari berbagai perbedaan asal usul pesantren, sejak didirikan pertama kali oleh Syech Maulana Malik Ibrahim pada tahun 1399 M,1 diteruskan oleh Raden Rahmat (Sunan Ampel) di Kembang Kuning, pesantren mampu terus berkiprah hingga hari ini. Dari zaman kolonial Belanda, orde lama, orde baru hingga reformasi, pesantren terus eksis dan mewarnai serta memberikan sumbangsih signifikan terhadap bangsa ini. Telah begitu banyak tokoh-tokoh kaliber dunia yang muncul dari pesantren, Syekh Nawawi al-Banten $\hat{\imath}$, Syaikhona Muhammad Kholil, dan KH. Hasyim Asy'ari merupakan contoh kongkrit kapabilitas alumnus pesantren.

Pondok pesantren juga terkenal dengan kebudayaannya yang khas, baik dari pola hidup yang bersahaja dan asketik, hingga tradisi pendidikan yang berkarakter. Tradisi pesantren ini selalu dijaga dengan hati-hati, bahkan dari awal berdirinya sampai hari ini. Seiring perputaran zaman, sistem yang dulu masih menjadi sesuatu yang kontemporer, sekarang telah menjelma menjadi sesuatu yang konvensional, dari yang paling modern menjadi tradisonal dan ortodoks. ${ }^{2}$

Dalam hal ini, Steenbrink mengatakan bahwa hampir semua pelapor Barat selalu memberikan laporan pertama kepada pembaca yang belum pernah mengunjungi pesantren, atau mengenalnya lewat tulisan. Pada umumnya mereka memberikan gambaran dan kesan aneh dan khusus menekankan adanya perbedaan dengan sekolah-sekolah barat. ${ }^{3}$

Walaupun begitu, bukan berarti tidak ada perubahan dalam khazanah pesantren, adigum "al-muhâfadatu 'alâ al-qadîmi al- șhâlih wa al-akhdu bi al-jadîdi alașlah" di sebuah keniscayaan terhadap perubahan. Hanya saja perubahanperubahan itu dulunya menjadi tidak begitu kelihatan. Snouck Hurgronje mengatakan:

\footnotetext{
1 Ada yang berpendapat pada abad 15. lihat Khamami Zada, dkk, Intelektualisme Pesantren (Jakarta: Diva Pustaka, 2003), 14. Kemudian ada yang mengatakan pada abad ke 13, Masyhud, Sulthon dan Khusnurdilo, Manajemen Pondok Pesantren (Jakarta: Diva Pustaka, 2003). 1.

2 Syaifullah Yusuf, Melahirkan Ilmuwan-Ulama: Tanggungjawab Ganda Pesantren di Era Kesejagatan, pengantar dalam Babun Suharto, Dari Pesantren untuk Umat (Surabaya: IMTIYAZ, 2011), xi.

${ }^{3}$ Karel A. Steenbring, Pesantren Madrasah Sekolah (Jakarta: LP3ES, 2002), 8.
} 
"Islam tradisional di Jawa yang kelihatannya demikian statis dan demikian kuat terbelenggu oleh pikiran-pikiran "ulama" di abad pertengahan, sebenarnya telah mengalami perubahan-perubahan yang sangat fundamental; tetapi perubahan-perubahan tersebut demikian bertahap, demikian rumit dan demikian tersimpan. Itulah sebabnya bagi para pengamat yang tidak kenal dengan pola pikiran Islam, maka perubahan-perubahan tersebut tidak akan bisa terlihat, walaupun sebenarnya terjadi di depan matanya sendiri, kecuali bagi mereka yang mengamatinya secara seksama"4

Perkembangan dan perubahan yang dilakukan pondok pesantren, sebagai bentuk konstalasi dengan dunia modern serta adaptasinya, menunjukkan kehidupan pondok pesantren tidak lagi dianggap statis dan mandeg. dinamika kehidupan pondok pesantren telah terbukti dengan keterlibatan dan partisipasi aktif memberikan pelayanan kepada masyarakat dalam banyak aspek kehidupan yang senantiasa menyertainya. di antaranya, ikut serta dalam upaya mencerdaskan kehidupan bangsa melalui lembaga pendidikan pesantren. karena pesantren merupakan lembaga pendidikan yang memiliki akar budaya yang kuat di masyarakat. ${ }^{5}$

Lebih lanjut, dalam iklim kompetitif seperti sekarang ini, sulit bagi pesantren untuk hidup dengan baik jika tidak memiliki kemampuan untuk mengubah diri dengan cepat dan mampu berkembang seiring dengan berbagai tuntutan stakeholder. kondisi ini berlaku hampir pada keseluruhan pesantren yang bersifat profit dan nonprofit. pesantren sebagai lembaga pendidikan yang termasuk lembaga nonprofit juga tidak terlepas dari fenomena ini, itulah sebabnya dalam banyak hal pesantren harus mengetahui berbagai harapan dan kebutuhan stakeholder.

Tidak perlu disangkal, ketika banyak kalangan memandang lemah bahkan mengklaim problematika internal pondok pesantren terletak pada kepemimpinan. terlepas dari keberhasilannya selama ini, pondok pesantren diakui, mampu mendidik para santrinya menjadi manusia yang shalih, menjadi mubaligh, serta para cendekiawan yang kemudian menjadi pemimpin di tengah-tengah masyarakat, baik formal maupun informal yang kini tersebar di seluruh pelosok nusantara ini. ${ }^{6}$

Secara umum kepemimpinan di pesantren kurang diperhatikan secara serius, karena pesantren sebagai lembaga tradisional, ${ }^{7}$ dengan wataknya yang bebas, sehingga pola pembinaannya hanya tergantung pada kehendak dan kecenderungan pimpinan saja. Padahal sesungguhnya potensi-potensi yang ada dapat diandalkan untuk membantu penyelenggaraan pondok pesantren.

Berangkat dari itu, menjadi sesuatu yang menarik untuk dikaji lebih intensif tentang pengelolaan yang ada di pesantren beserta faktor determinasinya, untuk

\footnotetext{
4 Zamakhsyari Dhofier, Tradisi Pesantren (Jakarta: LP3ES, 1994), 2.

5 Sa'id Aqiel Siraj, Pesantren Masa Depan (Bandung: Pustaka Hidayah, 1999), 181.

${ }^{6}$ Mahpuddin, Noor, Potret Dunia Pesantren (Bandung: Humaniora, 2006), 112.

7 Zamachsyari Dhofier, Tradisi Pesantren, (Jakarta: LP3ES, 1994), 3.
} 
menghasilkan data yang akurat, valid, dan objektif, sehingga diharapkan mampu menjawab permasalahan dengan semangat ilmiah yang bebas nilai.

\section{Dinamika Kepemimpinan di Pesantren}

Pondok pesantren ${ }^{8}$ merupakan lembaga pendidikan Islam yang menempatkan sosok kiai sebagai tokoh sentral dan masjid sebagai pusat lembaganya. ${ }^{9}$ Lembaga ini merupakan institusi pendidikan Islam tertua di Indonesia dan sekaligus bagian dari warisan budaya bangsa (indigenous culture). ${ }^{10}$ Maka, bukanlah kebetulan jika pesantren masih dapat bertahan hingga saat ini.

Mereka yang pernah mengenyam pendidikan pesantren, kemudian juga belajar di lembaga pendidikan lainnya. Baik di dalam maupun di luar negeri pada umumnya memandang bahwa pesantren tetap memiliki tempat terhormat sebagai lembaga pendidikan Islam khas Indonesia, yang dapat dirunut pertalian keilmuan dan kurikulumnya dengan pusat-pusat pembelajaran ilmu agama Islam diberbagai belahan dunia.

Optimisme itu biasanya mendasarkan pada bukti-bukti bahwa pesantren masih tetap terselenggara sejak ratusan tahun yang lalu, lulusannya dapat memainkan peranan yang berharga di bidang keilmuan atau kepemimpinan, dan belum ada lembaga pendidikan yang melahirkan ulama dari generasi ke generasi dalam kapasitas sebagaimana yang diluluskan oleh pesantren.

Seiring dengan perkembangan zaman, potensi pesantren sebagai intitusi pendidikan yang mengajarkan agama dan penekanan moral dipertanyakan. Muhammad Busyro mengatakan, jika dewasa ini terdapat dua pandangan masyarakat umum terhadap pesantren: Pertama mereka menyangsikan relevansi lembaga ini untuk menyongsong masa depan. Kedua mereka justru melihat pesantren sebagai sebuah alternatif model pendidikan masa depan. ${ }^{11}$

Melihat kenyataan ini, pondok pesantren mau tidak mau harus terbuka dengan dunia luar. Hal ini diulai sejak abad ke-20 dengan penerapan sistem konvergensi, yakni pemaduan kurikulum pesantren dengan kurikulum pemerintah. Sedikitnya ada dua cara yang harus dilakukan pondok pesantren, pertama merevisi kurikulum dengan memasukkan semakin banyak mata pelajaran umum atau bahkan keterampilan umum; kedua membuka kelembagaan dan fasilitas-fasilitas pendidikan bagi kepentingan pendidikan umum. ${ }^{12}$

Sistem konvergensi ini apabila dikelola dengan kepemimpinan yang baik akan memberikan peluang dan harapan terhadap pesantren menjadi lembaga

\footnotetext{
8 Mamfret Ziemek, Pesantren dalam Perubahan Sosial (Jakarta: P3M, tt), 116. DAN Zamahsyari Dhofier, Tradisi Pesantren: Studi tentang Pandangan HidupKiai, cet.VI (Jakarta: LP3ES, 1994), 18.

${ }^{9}$ Dawam Raharjo, Pesantren dan Pembaharuan, cet.V (Jakarta: LP3ES, 1995), 87.

10 Amal Fathullah Zarkasyi, Pondok Pesantren sebagai Lembaga Pendidikan dan Dakwah, dalam Adi Sasono, Didin Hafiduddin, AM. Saefuddin, dkk, Solusi Islam atas Problematika Umat, cet.I (Jakarta: Gema Insani Pers, 1998). 101-171.

11 Muhammad Busyro, Problem Pengembangan Tradisi Pesantren, dalam Abdul Munir Mulkham, Rekonstruksi Pendidikan dan Pustaka Tradisi Pesantren (Relegiusitas Iptek) (Yogyakarta: Fak Tarbiyah IAIN Sunan Kalijaga \& Pustaka Pelajar, 1998), 186-199.

12 Azyumardi Azra, Pendidikan Islam Tradisi dan Modernisasi menuju Milenium Baru (Jakarta: PT. Logos Wacana Ilmu, 1999), 102.
} 
yang mampu berperan melaksanakan pendidikan secara integral antara penanaman al-akhlak al-karîmah (moral) dan intelektual.

Neong Muhajir, ${ }^{13}$ pendapat yang berkaitan dengan dinamika dalam arti instrumentasi, antara lain: pendapat Durkheim yang mengatakan perubahan evolusioner dari mekanik ke organik. Pembagian kerja dan tata sosial yang semula kaku mendetail menjadi luwes. Sedangkan Homans mengatakan teori tukar menukar (exchange theory), bahwa manusia bertindak atas prinsip meminimalkan biaya dengan menjangkau keuntungan maksimal. Kekuatan (power) dimiliki oleh orang yang mampu memberi hadiah (keuntungan) lebih besar dalam tukar menukar dengan kesediaan menerima imbalan yang lebih kecil.

Lewis Coser mengatakan, peranan konflik sebagai pendorong perubahan sosial, dan mempunyai fungsi positif dan fungsi negatif dalam perubahan sosial, dan fungsi negatif konflik menimbulkan keraguan dan keseimbangan nilai sosial yang ada.

Dari beberapa pendapat diatas dapat disimpulkan bahwa perubahan bisa terjadi dengan evolusioner, dan dalam perubahan tersebut ada suatu kekuatan (power) yang menjadikan sesuatu itu dapat berubah. Dalam fenomena yang terjadi, hal ini menunjukkan bahwa suatu kekuatan yang ada di pesantren adalah sosok sentral, yaitu seorang kiai. Sedangkan pendorong yang dapat berperan mempercepat perubahan sosial menurut Neong Muhajir, setidak-tidaknya ada tiga macam: (1) Penemuan teknologi baru; (2) Wawasan baru; dan Perubahan struktur atau fungsi sesuatu satuan sosial. ${ }^{14}$

Suatu perubahan mungkin berpangkal pada yang pertama, mungkin pula bermula dari yang kedua atau yang ketiga. Tetapi ketiganya akhirnya menjadi saling mempengaruhi.

Bila hal tersebut dikaitkan dengan dinamika pondok pesantren, maka yang kedua banyak mewarnai perkembangan pondok pesantren yaitu pada wawasan seorang pemangku pondok, dalam hal ini adalah kiai. Karena setiap perubahan sosial pasti ada sosial aktornya, dan sosial aktor pada dinamika kepemimpinan pendidikan di pondok pesantren adalah kiai. Kiai merupakan power (kekuatan) dalam hal kedalaman ilmu kiai dan wawasan barunya untuk menghadapi perubahan. Seorang kiai sebagai pemangku pondok pesantren memiliki karisma. ${ }^{15}$ Dan pengaruhnya besar sekali dalam kehidupan masyarakat.

Di samping itu, kiai memiliki otoritas dan wewenang yang menentukan semua aspek kegiatan pendidikan dan kehidupan agama atas tanggung jawab sendiri. ${ }^{16}$ Kiai berperan sebagai alat penyaring arus informasi yang masuk ke lingkungan kaum santri, menularkan apa yang dianggap berguna dan membuang apa yang dianggap merusak bagi mereka. Namun, menurut Geertz, peranan

\footnotetext{
${ }^{13}$ Neong Muhajir, Teori Perubahan Sosial, dalam Ridlwan Nasir, Mencari Tipologi Format Pendidikan Ideal: Pondok Pesantren di Tengah Arus Perubahan (Yogyakarta: Pustaka Pelajar, 2005$), 12$.

14 Neong Muhajir, Metodologi Penelitian Kualitatif (Yogyakarta: Rake Sarusin, 1990), 11-12.

15 Zamakhsyari Dhofier, Tradisi Pesantren (Jakarta: LPES, 1982), 56. dan Bakhtiar Efendi, Nilai Kaum Santri dalam M. Dawan Raharjo, Pergulatan Dunia Pesantren (Jakarta: P3M, 1985), 50-51.

16 Manfred Ziemek, Pesantren dan Perubahan Sosial (Jakarta: P3M, 1986), 138.
} 
penyaring itu akan macet manakala arus informasi yang masuk begitu deras dan tidak mungkin disaring oleh sang kiai. Dalam keadaan demikian, kiai akan kehilangan peranannya. Dengan kurangnya informasi yang diperoleh, kiai menjadi tidak kreeatif, dan akan mengalami kesenjangan budaya (cultural lag) dengan masyarakat sekitarnya. ${ }^{17}$

Menurut Horikoshi, ada sebagian kiai berperanan kreatif dalam perubahan sosial. Hal ini bukan karena sang kiai mencoba meredam akibat perubahan yang terjadi, melainkan justeru karena mempelopori perubahan sosial dengan caranya sendiri. Ia bukan melakukan penyaringan informsi, melainkan menawarkan agenda yang dianggapnya sesuai dengan kebutuhan nyata masyarakat yang dipimpinnya. Ia bukan keraguan berperan karena menunda datangnya perubahan melalui proses penyaringan informasi, melainkan ialah sepenuhnya berperan karena ia mengerti bahwa perubahan sosial adalah perkembangan yang tak terelakkan lagi.

Untuk lebih jelas menggambarkan miniatur atau corak kepemimpinan kiai, berikut ini dipaparkan tentang tipe-tipe pemimpin, ${ }^{18}$ yaitu:

\section{Tipe Otokratik}

Pemimpin yang bertipe ini akan bertindak sendiri dalam mengambil keputusan, dan memberitahukan kepada bawahannya bahwa ia telah mengambil keputusan tertentu dan para bawahannya itu hanya berperan sebagai pelaksana karena mereka tidak dilibatkan sama sekali dalam proses pengambilannya. Gaya otokratik bukanlah gaya yang didambakan oleh bawahan dalam mengelola suatu organisasi kerena pentingnya unsur manusia sering diabaikan.

\section{Tipe Meliteristik}

Tipe ini dalam menggerakkan bawahan sering menggunakan cara mengambil keputusan sendiri dan berusaha "menjual" keputusan itu kepada bawahannya. Dengan harapan bahwa para bawahan akan mau menjalankannya meskipun tidak dilibatkan dalam proses pengambilan keputusan.

\section{Tipe Paternalistik}

Orientasi kepemimpinan dengan gaya ini memang ditujukan pada dua hal sekaligus, yaitu penyelesaian tugas dan terpeliharanya hubungan yang baik dengan para bawahan sebagaimana seorang bapak akan selalu memelihara hubungan yang serasi dengan anak-anaknya.

\section{Tipe Karismatik}

\footnotetext{
17 Hiroko Horikoshi, Kiai dan Perubahan Sosial (Jakarta: P3M, 1987), xvi-xvii.

18 Sondang P. Siagian, Filsafat Administrasi (Jakarta: Mas Agung, 1994), 41. dan lihat juga Sondang P. Siagian, Fungsi-Fungsi Manajerial (Jakarta: Bumi Aksara, 1992), 17. Bandingkan juga YW. Sunindhia dan Ninik Widayanti, Kepemimpinan dalam Masyarakat Modern (Jakarta: Asdi Mahasatya, 1993), 29., dan M. Karyadi, Kepemimpinan (Leadership) (Bandung: Karya Nusantara, 1989), 7-8.
} 
Seorang pemimpin yang bertipe karismatik mungkin saja bertindak otokratik dalam mengambil keputusan, dalam arti ia mengambil keputusan sendiri tanpa melibatkan para bawahannya dan menyampaikan keputusan itu kepada orang lain untuk dilaksanakan. Akan tetapi adakalanya ia menggunakan gaya yang demokratik, dalam arti mengikutsertakan para bawahan dalam pengambilan keputusan. Pemimpin yang demikian memiliki daya tarik yang amat besar dan karenanya pada umumnya mempunyai pengikut yang jumlahnya sangat besar. Sering dikatakan bahwa pemimpin yang demikian diberkahi dengan kekuatan gaib (supranatural power), mempunyai semacam kesaktian, dan mempunyai kemampuan yang luar biasa diluar kemampuan orang-orang biasa.

\section{Tipe Demokratik}

Pemimpin yang bertipe demokratik akan memilih model dan teknik pengambilan keputusan tertentu yang memungkinkan para bawahannya berpartisipasi, dan gaya ini dipandang sebagai gaya yang paling didambakan oleh semua pihak yang terlibat dalam pencapaian tujuan organisasi yang bersangkutan.

Tipe kepemimpinan kiai menurut konsep Islam, disebut tipe kepemimpinan wilayah al-imam. Menurut penulis, tipe tersebut agak memiliki kaitan erat dengan pembagian konsep kekuasaan yang dikelompokkan oleh Weber ${ }^{19}$ dalam tiga kategori, meskipun tidak sepenuhnya tepat. Tipe kepemimpinan kiai bila ditinjau dari kategori yang dikemukakan oleh Weber, dapat dimasukkan dalam kepemimpinan tradisional, karismatik, dan rasional. Otoritas kepemimpinan seorang kiai dapat terus bertahan selama tradisi pesantren masih terpelihara, dan kekuasaan karismatik dari pribadi seorang kiai memancarkan pesonanya, serta tipe kepemimpinan yang bersifat kolektif berbentuk Majelis Pimpinan Pondok.

Sehubungan dengan itu, gaya kepemimpinan yang ada di pondok pesantren yang dijadikan obyek penelitian, memiliki ciri paternalistik dan laissez faire, di mana pemimpin sebagai seorang bapak yang memberikan kesempatan kepada anak-anaknya untuk berkreasi, dan juga pemimpin pasif karena dia akan mendelegasikan seluruh tugas-tugas itu kepada bawahannya. Kehadirannya sebagai pemimpin dipandang terutama sebagai simbol keberadaan organisasi ketimbang sebagai pembina, pengarah atau penggerak. Tetapi juga memiliki tipe otoriter, yang memberikan kata-kata final untuk memutuskan apakah anak buah yang bersangkutan dapat diteruskan atau harus dihentikan. Sementara itu, bila dilihat dari pengoperasian ta'dim (hormat) santri kepada kiai begitu besar, maka termasuk tipe karismatik.

\section{Model Kepemimpinan Pesantren}

19 Noeng Muhajir, Kepemimpinan Adopsi Inovasi untuk Pembangunan Masyarakat (Yogyakarta: Rake Sarasin, 1987), 9. 
Masyarakat Indonesia yang pada umumnya beragama Islam lebih-lebih di daerah pedesaan yang relegius, nampaknya membutuhkan kepemimpinan rohaniah yang dipenuhi oleh lembaga pesantren yang merupakan pusat kegiatan spiritual. Kepemimpinan rohaniah dibutuhkan dalam masyarakat pertanian untuk menjaga keharmonisan yang selalu didambakan di lingkungan ini.20 Kegiatan-kegiatan keagamaan seperti shalat berjama'ah di masjid, kuliah subuh, dan upacara perkawinan, adalah hal-hal yang mengisi dan memberi makna hidup pada masyarakat desa.

Kiai dipandang sebagai tokoh ideal oleh komunitas pesantren dan sebagai sentral figur yang mewakili keberadaan mereka. Peran kiai dalam pandangan ideal tersebut sangat vital, sebagai mediator, dinamisator, katalisator, motivator maupun sebagai power bagi masyarakat yang dipimpinnya. Sebab, keberadaan kiai bagi masyarakat pesantren yang dipimpinnya bukan sekedar menjadi wakil untuk menjalin hubungan dengan dunia di luar pesantren, melainkan juga dalam rangka melindungi kepentingan masyarakat dan lembaga-lembaga Islam.

Seorang kiai sebagai pemilik dan pemimpin pesantren yang mempunyai kuasa dan pengaruh dapat mengembangkan berbagai keterampilan atau pendidikan kesejahteraan keluarga, kepramukaan, koperasi, pusat informasi atau program lainnya sesuai dengan kebutuhan masyarakat. Namun seorang kiai juga harus hati-hati dalam mengambil suatu langkah perubahan-perubahan pembaharuan.

Kepemimpinan kiai dapat berpola karismatik, maksudnya suatu pola kepemimpinan yang mengacu pada satu figur sentral yang dianggap oleh komunitas pendukungnya memiliki kekuatan supranatural dari Allah, kelebihan dalam berbagai bidang keilmuan, partisipasi komunitas dalam mekanisme kepemimpinan kecil, dan mekanisme kepemimpinan tidak diatur secara birokratik. Kemungkinan yang lain, bahwa pola kepemimpinan kiai adalah tradisional, maksudnya suatu pola kepemimpinan yang membutuhkan legitimasi formal komunitas pendukungnya dengan cara mencari kaitan keturunan dari pola kepemimpinan karismatik.

Disamping dua pola tersebut di atas, dapat pula kepemimpinan kiai adalah rasional yakni pola kepemimpinan yang mengacu pada satu pola kepemimpinan yang bersifat kolektif, di mana tingkat partisipasi komunitas lebih tinggi, struktur keorganisasian lebih kompleks, dan sentral kepemimpinan tidak mengarah kepada satu individu melainkan mekanisme kepemimpinan diatur secara manajerial.

Dari ketiga sistem tersebut, menurut penulis, sistem kolektif dipandang lebih sesuai untuk memacu perkembangan pendidikan pondok pesantren. Dengan alasan bahwa berangkat dari perlunya kesinambungan pesantren itulah, timbul pemikiran bahwa kepemimpinan pesantren itu bila dipandang perlu bisa saja diteruskan oleh orang-orang bukan dari keluarga kiai pendiri sebagai pemiliknya. Usulan ini bukan hanya menyimpang dari kebiasaan selama ini, yaitu

20 Ridlwan Nasir, Mencari Tipologi Format Pendidikan Ideal: Pondok Pesantren di Tengah Arus Perubahan, (Yogyakarta: Pustaka Pelajar, 2005). 22 
pewarisan penerusan kepemimpinan pesantren kepada putranya bila kiai pendahulu meninggal dunia, namun masalahnya berkaitan dengan soal rela atau tidaknya pihak keluarga bila kepemimpinan diteruskan oleh orang lain.

Oleh sebab itu, muncul semacam usulan diterapkannya pola kepemimpinan kolektif sejak kiai pendiri masih hidup. Dalam kepemimpinan ini, kiai sepuh selain melibatkan putranya juga memasukkan orang kepercayaan dalam kepemimpinan pesantren. Dengan demikian, ketika kiai sepuh meninggal dunia, kesinambungan eksistensi pesantren bisa diselamatkan oleh kepemimpinan kolektif tadi, atau yayasan yang ada memiliki kiai yang dianggap mampu melanjutkan kepemimpinan (tidak harus dari keturunan kiai).21

Adapun bahasan tentang dinamika perubahan sosial dalam arti tujuan akan dipaparkan sebagai berikut:

Agus Comte mengatakan teori perubahan masyarakat dari periode teologik melalui metaphisik ke positivistik. Nampaknya Agus Comte menyusun periodisasi perubahan sosial berdasar pengamatan perkembangan sejarah alam pikir pada abad 17. Bila perubahan sosial tetap dipandang sebagai proses maju, maka cara berpikir teologik dilihat lebih rendah dari yang metaphisik, dan yang metaphisik lebih rendah dari cara berpikir positivistik. ${ }^{22}$ Durkheim dengan teori evolusinya mengetengahkan perubahan sosial dari solidaritas mekanik ke solidaritas organik. Sedangkan Max Weber mengetengahkan teori perkembangan ke masyarakat yang lebih rasional. Dengan demikian, pola pikir non rasional dilihat oleh Weber sebagai taraf perkembangan kurang maju. Dalam satu segi ada paralelnya dengan jalan pikiran Comte..$^{23}$

Banyak pesantren yang meningkatkan fungsi kemasyarakatan disamping menyelenggarakan pendidikan. Misalnya terlibat langsung dalam pengembangan masyarakat sekitarnya. Di bidang pendidikan, juga banyak yang menyelenggarakan pendidikan formal dengan berbagai tingkatan, disamping tetap menyelenggarakan pengajian kitab-kitab kuning.

\section{Komponen yang Dikembangkan dalam Kepemimpinan Pesantren}

Usaha-usaha untuk mengembangkan potensi dan meningkatkan peranan Pondok Pesantren sebagai lembaga pendidikan dan lembaga pencetak ulama dan pemimpin masyarakat ini sering di adakan. Usaha ini tercermin dalam berbagai musyawarah, diskusi dan seminar, baik yang diadakan oleh Pondok Pesantren sendiri, lembaga swasta maupun yang di adakan Pemerintah kesemuanya berkesimpulan akan pentingnya peningkatan dan pembinaan Pondok Pesantren agar tetap bahkan lebih mampu berfungsi secara efektif dalam masa pembangunan dewasa ini.

\footnotetext{
${ }^{21}$ Ridlwan Nasir, Mencari Tipologi Format Pendidikan Ideal: Pondok Pesantren di Tengah Arus Perubahan, (Yogyakarta: Pustaka Pelajar, 2005). 24-25

22 Noeng Muhajir, Kepemimpinan Adopsi Inovasi untuk Pembangunan Masyarakat (Yogyakarta: Rake Sarasin, 1987), 17

${ }^{23}$ Noeng Muhajir, Kepemimpinan Adopsi Inovasi untuk Pembangunan Masyarakat (Yogyakarta: Rake Sarasin, 1987), 18
} 
Dalam rangka dinamisasi, modernisasi dan reformasi Pondok Pesantren, Pemerintah telah mengintrodusir beberapa komponen kegiatan pada tiap pesantren, sebagai berikut:24

\section{Pengajian (pendidikan dan pengajaran agama)}

Pengajian adalah kegiatan pendidikan keagamaan yang penyelenggaranya sepenuhnya di serahkan pada kebijakan Bapak Kiai. Sistem penyampaian yang di pergunakan biasanya dalam bentuk sorogan, bandongan, wetonan atau jenis-jenis lainnya. Kegiatan ini di maksudkan guna mendalami ajaran agama, sehingga terpeliharanya kelestarian pendidikan keagamaan untuk memelihara calon ulama.

\section{Pendidikan formal}

Pendidikan formal diselenggarakan terutama dalam bentuk madrasah. Dengan membina dan mengembangkan pendidikan formal di Pondok Pesantren, diharapkan sebagian lulusan Pondok Pesantren akan memilki pengetahuan akademis dan dapat melanjutkan pendidikannya kejenjang sekolah atau lembaga pendidikan yang lebih tinggi.

\section{Pendidikan kesenian}

Pendidikan kesenian dimaksudkan untuk lebih meningkatkan apresiasi para santri terhadap macam-macam bentuk kesenian. Selama ini di kalangan Pondok Pesantren sudah berkencang seni barzanji, shālawatan, pencak silat dan lain lainnya. Dengan pendidikan kesenian ini di harapkan para santri mempunyai orientasi yang lebih luas dalam kegiatan kesenian, yakni tidak saja pada jenis kesenian yang bersifat nasional dan universal, namun tetap dalam batas-batas ajaran agama Islam.

\section{Pendidikan keterampilan kejuruan}

Pendidikan ketrampilan kejuruan di kembangkan di Pesantren, untuk keperluan santri sebagai modal untuk menjadi manusia yang bersemangat wiraswasta dan sekaligus untuk menunjang pembangunan lingkungan. Disamping itu, pendidikan ketrampilan ini diperlukan dalam rangka menyeimbangkan antara perkembangan otak, hati dan ketrampilan.

\section{Faktor Penghambat \& Penunjang Kepemimpinan Pendidikan Pesantren}

Abudin Nata menyebutkan; dewasa ini pendidikan Islam terus dihadapkan pada berbagai problema yang kian kompleks. karena itu upaya berbenah diri melalui penataan SDM, peningkatan kompetensi dan penguatan institusi mutlak harus dilakukan dan semua itu mustahil tanpa kepemimpinan yang profesional..$^{25}$

Seperti diketahui bahwa sebagai sebuah sistem pendidikan Islam mengandung berbagai komponen yang saling berkaitan satu sama lain. Komponen tersebut meliputi landasan tujuan kurikulum kompetensi dan

24 Amin Abdullah, Langkah Pengembangan Pesantren, dalam http://www.raudlotuttolabah.com /2010/10/langkah-pengembangan-pesantren.html. (20 Januari 2011)

25 Abudin Nata, Sejarah Pertumbuhan dan Perkembangan Lembaga-lembaga Pendidikan Islam di Indonesia (Jakarta: Grasindo, 2003), 19. 
profesionalisme guru, pola hubungan guru dan murid, metodologi pembelajaran sarana prasarana evaluasi pembiayaan dan lain sebagainya. Berbagai komponen ini dilakukan tanpa perencanaan dan konsep yang matang seringkali berjalan apa adanya. alami dan tradisional akibat mutu pendidikan Islam acapkali menunjukkan keadaan yang kurang membanggakan.

Problematika yang dihadapi pondok pesantren dikarenakan adanya kendala pada perencanaan pondok pesantren yang kurang optimal. sehingga dalam pelaksanaan fungsi tugasnya tdak berjalan sebagaimana yang diharapkan. juga disebabkan minimnya personil yang kompeten pada bidangnya, dan sumber dana kurang memadai.

Dalam penyusunan perencanaan program kerja hendaknya diperhitungkan secara terperinci tentang kondisi obyektif pondok pesantren, pemasalahan, alternatif pemecahan, faktor pendukung dan penghambat program, prioritas pengembangan program, indikator keberhasilan dan langkah-langkah mencapai keberhasilan program, pengalokasian dan waktu dalam mencapai tujuan yang telah ditetapkan. Jika perencanaan disusun dengan jelas dan bersifat terbuka serta rasional maka tujuan dapat mudah dicapai.

\section{Penutup}

Berdasarkan pemaparan hasil penelitian dan pembahasan di atas, maka dapat disimpulkan sebagai berikut:

1. Dalam dinamika kepemimpinan pesantren, kiai merupakan figur sentral di dunia pesantren dan lebih dari itu merupakan faktor determinan terhadap suksesnya santri dalam mencari pengetahuan. Dalam ranah akademik pendidikan pesantrenan, signifikasi peranan kiai dalam mengambil kebijakan juga menjadikan pembelajaran di pesantren yang biasanya non-stop, ketidak teraturan kurikulum, atau bahkan ada pesantren yang sama sekali tidak menerapkan sistem kurikulum.

2. Komponen-komponen yang di kembangkan dalam kepemimpinan pesantren adalah memberikan rasa tanggungjawab kepada bawahan, dalam hal ini lebih dititikberatkan pada program formal lebih diprioritaskan pada lembaga pendidikan (sekolah/madrasah). Sedangkan non-formal diprioritaskan pada lembaga pendidikan pendidikan pesantren, seperti seperti kajian tindak lanjut ilmu nahwu, halaqah tadarus kitabiyah, bina tajwid dan tartil.

3. Faktor penghambat kepemimpinan di pondok pesantren antara lain: 1) Sumber daya Santri; 2) Dana Pendidikan yang kurang mencukupi operasionalisasi pendidikan; 3) Sarana Pra-sarana belum memadai; 4) Kurang lengkapnya fasilitas pesantren; dan 5) Minat masyarakat yang mengalami perubahan kecenderungan terhadap nilai antara salafiyah dan modern. Faktor penunjang dari manajemen pendidikan pesantren, antara lain: Adanya sarana pendidikan yang berorientasi pada pengembangan santri, seperti: perpustakaan, media informasi, lingkungan yang kondusif, serta lembaga-lembaga otonom yang membantu santri mengakomodir bakat dan minatnya untuk berkembang. 


\section{DAFTAR PUSTAKA}

Azra, Azyumardi, Pendidikan Islam Tradisi dan Modernisasi menuju Milenium Baru, (Jakarta: PT. Logos Wacana Ilmu, 1999).

Dhofier, Zamahsyari, Tradisi Pesantren: Studi tentang Pandangan HidupKiai, cet.VI, (Jakarta: LP3ES, 1994).

Horikoshi, Hiroko, Kiai dan Perubahan Sosial, (Jakarta: P3M, 1987).

Karyadi, M., Kepemimpinan (Leadership), (Bandung: Karya Nusantara, 1989).

Mahpuddin, Noor, Potret Dunia Pesantren, (Bandung: Humaniora, 2006).

Masyhud, Sulthon dan Khusnurdilo, Manajemen Pondok Pesantren, (Jakarta: Diva Pustaka, 2003).

Muhajir, Noeng, Kepemimpinan Adopsi Inovasi untuk Pembangunan Masyarakat, (Yogyakarta: Rake Sarasin, 1987).

Mulkham, Abdul Munir, Rekonstruksi Pendidikan dan Pustaka Tradisi Pesantren (Relegiusitas Iptek), (Yogyakarta: Fak Tarbiyah IAIN Sunan Kalijaga \& Pustaka Pelajar, 1998).

Nasir, Ridlwan, Mencari Tipologi Format Pendidikan Ideal: Pondok Pesantren di Tengah Arus Perubahan, (Yogyakarta: Pustaka Pelajar, 2005).

Nata, Abudin, Sejarah Pertumbuhan dan Perkembangan Lembaga-lembaga Pendidikan Islam di Indonesia, (Jakarta: Grasindo, 2003).

Raharjo, M. Dawam, Pesantren dan Pembaharuan, cet.V, (Jakarta: LP3ES, 1995). Pergulatan Dunia Pesantren, (Jakarta: P3M, 1985).

Sasono, Adi, Didin Hafiduddin, AM. Saefuddin, dkk, Solusi Islam atas Problematika Umat, cet.I, (Jakarta: Gema Insani Pers, 1998).

Siagian, Sondang P., Filsafat Administrasi, (Jakarta: Mas Agung, 1994). , Fungsi-Fungsi Manajerial, Jakarta: Bumi Aksara, 1992).

Siraj, Sa'id Aqiel, Pesantren Masa Depan, (Bandung: Pustaka Hidayah, 1999).

Steenbring, Karel A., Pesantren Madrasah Sekolah, (Jakarta: LP3ES, 2002).

Suharto, Babun, Dari Pesantren untuk Umat, (Surabaya: IMTIYAZ, 2011).

Sunindhia, YW. dan Ninik Widayanti, Kepemimpinan dalam Masyarakat Modern, (Jakarta: Asdi Mahasatya, 1993).

Zada, Khamami, dkk, Intelektualisme Pesantren, (Jakarta: Diva Pustaka, 2003).

Ziemek ,Manfred, Pesantren dan Perubahan Sosial, (Jakarta: P3M, 1986). 